IRA-International Journal of Management \& Social Sciences

ISSN 2455-2267; Vol.06, Issue 01 (2017)

Pg. no. 31-36

Institute of Research Advances

http://research-advances.org/index.php/RAJMSS

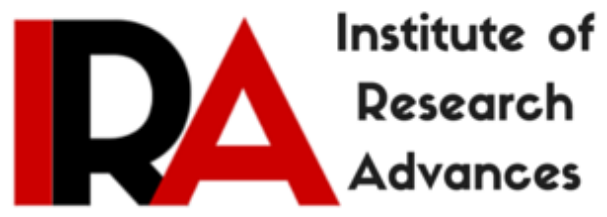

\title{
Insurgency in Nigeria: The Real Test of Nationhood
}

\author{
Zachariah Apamshan $^{1}$, Norafidah Ismail $^{2}$ \& Knocks Tapiwa Zengeni ${ }^{3}$ \\ ${ }^{1,2,3}$ Ghazali Shafie Graduate School of Government \\ Universiti Utara Malaysia, \\ 06010 UUM Sintok, Kedah, Malaysia.
}

Type of Review: Peer Reviewed.

DOI: http://dx.doi.org/10.21013/jmss.v6.n1.p5

How to cite this paper:

Apamshan, Z., Ismail, N., \& Zengeni, K. (2017). Insurgency in Nigeria: The Real Test of Nationhood. IRA-International Journal of Management \& Social Sciences (ISSN 2455-2267), 6(1), 31-36. doi:http://dx.doi.org/10.21013/jmss.v6.n1.p5

(C) Institute of Research Advances

\section{(oc) EY-NC}

This work is licensed under a Creative Commons Attribution-Non Commercial 4.0 International License subject to proper citation to the publication source of the work.

Disclaimer: The scholarly papers as reviewed and published by the Institute of Research Advances (IRA) are the views and opinions of their respective authors and are not the views or opinions of the IRA. The IRA disclaims of any harm or loss caused due to the published content to any party. 


\begin{abstract}
The Boko Haram and the Niger Delta militancy today remain unarguably the greatest security threats to the corporate existence of the Nigerian state and her development. At the root of these insurgencies are socio-economic, ethno-political and religious challenges which are actually byeproducts of a dysfunctional system. This research work examines the issues and challenges as it relates to the real test of Nigeria's nationhood. The research work made use of content analysis through the use of books, newspapers, journal publications and available sources from the internet library. This is to give a deeper understanding of the issues that surround insurgency in Nigeria with a view of proffering solutions. The findings of this research work reveals that, lack of employment and equal opportunities especially for the youths of the minority tribes who make up the people of the Niger Delta region are seen as the root cause of agitations. Also, the findings discloses poor and ineffective governance as responsible for the increased social and political uncertainties, rigidity and institutional failure. Issues such as religion, ethnicity, and regional sentiments were the real problems behind the violent conflict in Nigeria.
\end{abstract}

Keywords: Nigeria, insurgency, Boko Haram, militancy, Niger Delta

\title{
Introduction
}

The world over, insurgency has being a nightmare to governments in power, nations, and the international community with its impacts felt around the globe. The work of Aro (2013) indicates factors that are responsible for insurgency in Nigeria today as unemployment, ideological belief, poverty, social injustice, poor governance and marginalization of the people within a given entity. The work also attributes the effects of insurgents' activities as it promotes, mutual suspicion and fear of the unknown. These has been proven through the fear of the Youths corps members who were to serve in those states where the predominant activities of the Boko Haram insurgents persist in Northern Nigeria.

More so, insurgency in Nigeria as expressed by Suleiman \& Karim (2015) connotes that the gap between the rich and poor which fuels social and economic injustice as a result, creates and breeds militancy in Nigeria. Militancy in the West African sub-region as in the case of Nigeria, is being witnessed in both the Northern and Southern part of the country-the Boko Haram and the Niger Delta militancy respectively. Aghedo and Osumah (2012) blame poor political leadership in northern Nigeria especially over the years without providing the basic needs of the citizens as being responsible for the violent uprising in Nigeria. This research work seeks to unfold those real national issues that unite or otherwise destroy the Nigerian state. It has been proven beyond doubt that the Niger Delta question remains a great threat to the government and the security of the Nigerian state since the youths had been up in arms in the past and most especially during the military era in the early 90 s and the period of the return to democratic rule in 1999.

Nigeria has experienced series of insurgents' attacks which has hampered the growth and development of the country. As such, these attacks are observed as the real test of nationhood in a country known for her diversity in terms of ethnic and religious differences. The work of Igwara (2001) explores the differences between the minorities and majority ethnic dominance in Nigeria with a view of understanding rivalry between the groups. Dominance especially by the ethnic majority creates room for rivalry which also promotes mistrust and security challenges when sensitive national issues are mismanaged or neglected. The key issue surrounding dominance is the quest for identity and question of who controls what among the nationalities as seen in the Nigerian politics. This view captures the worries of other regions of the country about the long stay in power by the Northern ethnic nationalities especially the Hausa/Fulani from 1966 to 1976, 1979 to 1999 where the leaders who ruled the country within these periods were of the Northern ethnic extractions (Terwase, AbdulTalib, Zengeni \& Terwase, 2015).

This paper therefore, intends to bring to the fore those issues that are seen to be the real test of nationhood in relation to the activities of insurgency in Nigeria over time. The work would further bring out those elements that could strengthen the nation through her diversities such as ethnic, 
political, social, religious and sectional divides. In the past, Nigeria had experienced ethnic and political violence especially during the\# civil war that stood as a test for nationhood where many pundits thought the nation Nigeria would end up disintegrating. The Nigerian civil war in this case, lasted for three years from 1967 to 1970 which Nigeria lost over two million lives yet, the country was able to remain one indivisible entity as against the secession that was clamoured for by the Eastern Region of the Country at the time (Uzokwe, 2003).

\section{Objective of the Paper}

This research paper focuses on the following objectives:

i. $\quad$ To assess the phases of insurgency in Nigeria's Fourth Republic.

ii. To examine the issues and challenges as it relates to the real test of Nigeria's nationhood.

iii. The paper seeks to unveil the Nigerian security situation.

\section{Methodology}

The research work made use of content analysis through the use of books, newspapers, journal publications and available sources from the internet library. This is to give a deeper understanding of the issues that surround insurgency in Nigeria with a view of proffering solutions.

\section{Findings}

The findings from the research would be discussed below in relation to this work.

\section{The Phases of Insurgency in Nigeria's Fourth Republic}

There are phases of insurgency in Nigeria's Fourth Republic from 1999 to date (2016) where the country witnessed the activities of insurgents such as the Niger Delta groups from the southern part of the country and that of the Boko Haram insurgent group from the Northern part of the country. The Nigerian State went through the leadership of the military before the Fourth Republic which experienced various degrees of attacks by insurgent groups from the Niger Delta region of the country. The work of Terwase, Abdul-Talib \& Zengeni (2015) observed that the military rule in Nigeria lasted for many years during their takeover of power from 1966-1979 and 1983-1999.

Ikelegbe (2005) brought to the fore the knowledge on how the Niger Delta militants had kidnapped oil workers employed by Shell Petroleum Company to a number of 50 in September, 1999. It was noticed that the agitation for self-determination in the Niger Delta took a new turn in the 1990s as a result of the poor environmental development of the said region. The current crisis of small arms and light weapons in the Niger Delta started in the early 1990s as a result of tension between the Multinational oil Corporations such as Shell Petroleum Development Company (SPDC) and many of the ethnic minorities such as the Ogonis, Ijaws and the Itsekiris who felt terribly cheated. The area has always been regarded as a violent conflict theatre where crimes such as kidnapping of oil workers, vandalization of oil pipelines, bunkering and many other illegal activities take place. This was shortly before the military government handed over power in 1999 to a democratically elected government. The research work of Ikelegbe (2005) further explained the issues that led to insurgency in the region from mere agitation for resource control. These issues were aligned to continuous hegemonic rule of the Northern oligarchy. The key issues as raised by the Niger Delta insurgents includes neglect of the region in terms of infrastructural development as well as lack of capacity building of the people considering the quantum of resources that are extracted from the region which are used in the development of major cities across Nigeria. This and lack of employment and equal opportunities especially for the youths of the minority tribes who make up the people of the Niger Delta region as the root cause of agitations.

The Niger Delta's calls on the government to address the issues that were affecting them and their area were not adequately handled by the government. The ineptitude of successive of governments transformed their agitation from peaceful anti-oil protests to another phase where the youths began 
carrying arms against the government and the Multinational Companies operating in the region (Aghalino, 2004; Ikelegbe, 2006). These forms of transformation from mere agitation to violent struggle in the Niger Delta region became internationally known when many youths became involved and putting up their demands against the government to meet up with the challenges in the said region. At this stage, many groups were formed within the region as militants groups for the purpose of demonstrating their grievances and calling on the government to resolve the affected issues.

Another phase of insurgency in Nigeria's Fourth Republic is the Boko Haram insurgency whose group started violent attacks against the country in 2009 to date (2016). Their origin began in 2002 with a clear message of establishing an Islamic State in Nigeria. The violent nature of the Boko Haram in 2009 was spearheaded by their leader in person of Yusuf Mohammed when they launched their attacks on the Nigerian State and the security agencies (Walker, 2012). It is believed by the group that Western Civilization as well as their democratic liberal rules is forbidden. That the Nigerian state should be strictly governed by sharia rules and principles as seen in the works of several scholars (Suleiman \& Karim, 2015; Onapajo \& Uzodike, 2012; Onapajo, Uzodike \& Whetho, 2012). The Boko Haram group has never believed and recognised the Nigerian state due to its western ideology.

\section{Issues and Challenges to Nigeria's Nationhood}

The question of Nigeria's nationhood dates back to when the Colonial Government cobbled ethnic nationalities together through the amalgamation of the Southern and Northern Protectorates in 1914 by a political fiat. Many of the ethnic nationalities that make up Nigeria today hardly knew each other in terms of political, social or cultural diversities, as well as religious differences, before they were forcefully put together (Alubo, 2004). Chief Obafemi Awolowo, a foremost Nationalist simply described the cobbling of diverse ethnic groups by the colonial power without considering the challenges of integration and nation-building afterward as the 'mistake of 1914'.

It is thus, believed that the differences in Nigeria today emanate from her diversities in relation to ethnicity, religion and sectional divides where citizens generally lack sense and spirit of nationalism and patriotism. The problem in Nigeria's nation-building is not whether her indivisibility is in doubt but the nature of her unity where ethnicity, religion and political affiliations would make her a stronger, virile and more stable state. As it is today, those issues remain a great impediment to Nigeria on her match to fulfilling her full potentials as a nation. Successive Governments since Nigeria was created made nation-building a priority. However, the process has not been without difficulty which has often led to violence such as ethno-religious crises, war, secession (1990 attempted Military coup) where a large part of northern Nigeria was declared excised from the country.

More worrisome is the issue of 'indigenes-settlers' within the same country. Forest (2012) sees the difference between indigenes and non-indigenes or settlers as being a great force underlying violent conflicts and insurgency in Nigeria. The majority ethnic group within a geo-political space treat Nigerians from other parts of the country as settlers. Instances abound where children born to settlers are denied birth/indigene certificates and are asked to return to state of origin of parents to acquire such vital official documents. Where such certificate is issued, state of origin of parents is recorded as same for the child. These issues are fundamental and are a real test of Nigeria's nationhood.

Good governance promotes quality leadership, efficient and accountable wealth distribution. Poor and ineffective governance produces increased social and political uncertainties, rigidity and institutional failure. Nigeria has grappled with serious leadership changes and challenges as a result of inconsistencies from military to civil-civil to military governments (Rogers \& Hall, 2003). Ikelegbe (2006) in his work attributes the key security issues in the oil-rich Delta to the neglect and marginalization of ethnic minorities in the region. This view in line with the neglect of the region posit lack of political will on the side of the leaders to address underdevelopment, social and political injustice affecting the people in the Niger Delta. Issues such as that of ecological imbalance as a result of the oil activities in the Delta pose threats to the national security of the nation. Conservation and effective management of the environment brings about national survival. Oil spillage, gas-flaring, release of chemical waste from the oil wells, burst pipes and the inability of the oil multinationals to 
carry their host communities along in social and corporate emanates militancy and insurgency with the region.

Another issue is that of economic inequality where a tiny political class is excessively rich with full control of the resources and the power to allocate them leaving a greater percentage of the populace suffering lack. A great sense of economic and spiritual insecurities in the far northern part of Nigeria has been responsibly the driving force behind Islamist militancy in that part of the country.

\section{The Nigerian Security Environment}

The security environment within the Nigerian space especially in this Fourth Republic where the security apparatus of the state are completely under democratic control is indeed a complex and intriguing one where criminals and terrorists thrive. Under the current democratic dispensation in Nigeria, there is an awesome freedom of expression by both individuals and the corporate world. The media expresses opinions that are critical of governments across the three tiers of governments which was not the case under military leadership. That freedom of expression and association enabled the various interest and ethnic as well as political groups to create different pressure and militant groups which the military would not allow under any guise. The current security challenges in Nigeria today only bring to the fore the reality of socio-economic disparity and other deep seated challenges within the Nigerian society. Those communities and regions claimed by insurgency were first of all over-run by poverty and social deprivation. The rate of infant mortality, poverty and low educational enrolment as well as lack of access to quality healthcare are highest in communities worst hit by the insurgency in Nigeria compared with the other parts of the country.

Radical Islamists in the north especially the north-east have taken advantage of the near absence of governance in the region to question the authority of the governments both federal and state in the region. This group challenges the authority of the Nigerian state through imposition of their extreme ideology that was capable of causing a social change. The Boko Haram insurgents through their ideological stance capitalised on the failure of government and the frustration of the people within the society to mobilise large army of the unemployed youths against constituted authority (Mockaitis, 2011). In the Delta region of Nigeria, the destruction of the eco-system as a result of oil activities that have taken away the livelihoods of the locals such as fishing and crop cultivation with lack of access to quality basic needs from the huge oil revenues puts the people of the region in deep frustration. The perpetual destruction of the environment without re-engagement of the unemployed youths of the region by the oil multinationals and successive governments set the tune for the formation of militant gangs, criminal groups and ethnic militias that have metamorphosed into the national security nemesis today called Niger Delta Militancy.

The violent Niger Delta groups have over the years engaged in criminal activities such as oil bunkering, bombing of oil installations, kidnapping of both local and expatriate workers for ransoms, piracy, seizing and diverting of oil vessels in the high seas and exchanging such for arms amongst others. Furthermore, with the porous borders Nigeria has with her neighbours which also allow these jobless youths especially the Boko Haram in the North-east to engage in transnational crimes such as smuggling of small arms and light weapons, armed banditry, drugs and cattle rustling. The Nigerian civil war lasted for only three years (1967-1970) while both Boko Haram insurgency and the Niger Delta militancy have lasted more than thrice the years Nigeria spent in fighting her civil war. The military deployments to contain these two violent groups has steadily increased over time. President Goodluck Jonathan ordered the deployment of over 8000 troops for a direct military offensive against the Boko Haram insurgents in the north-east when he declared a state of emergency in the region. Since then, troops deployment to both the Niger Delta and the north-east has steadily being on the increase especially with the establishment of 6 and 7 Divisions of the Nigerian Army headquartered in Port Harcourt and Maiduguri respectively.

\section{Conclusion}

This research has exposed those fundamental issues such as poverty, bad governance, religion, ethnicity and the sharp socio-political divisions within the Nigerian system that have given rise to the 
insurgency the country now faces as the greatest threat to her existence. Nigeria ever remains one of the few nations across the globe so endowed with great human and material resources that are yet to maximise their full potentials. Those communities and regions worst hit by the extreme violence in Nigeria were first and foremost overtaken by extreme poverty and lack of any future hope orchestrated by bad governance and corruption. The challenges facing the country today are clear expression of the socioeconomic realities of the two most disadvantaged regions in Nigeria the southsouth and the north-east region which are the worst affected by the terrorists acts ravaging Nigeria.

\section{References}

- Agbiboa, D. E. (2013). Boko Haram, the Nigerian State and Spiralling Violence in Nigeria. The Africa Executive, June 2-12. Available at www.africanexecutive.com/modules/magazine/articles.php?article $=7259$

- Aghalino, S.O. (2004). Combating the Niger Delta Crisis: An Appraisal of Federal Government Response to Anti-oil Protests in the Niger Delta, 1958-2002. Maiduguri Journal of Historical Studies, 2(Issue 1).

- Aghedo, I. \& Osumah, O. (2012) The Boko Haram uprising: How should Nigeria respond? Third World Quarterly, 33, 853-869.

- Aro, O. I. (2013). Boko Haram Insurgency in Nigeria: Its Implication and Way Forwards toward Avoidance of Future Insurgency. International Journal of Scientific and Research Publications, Volume 3, Issue 11

- Igwara, O. (2001) Dominance and difference: rival visions of ethnicity in Nigeria. Ethnic and Racial Studies, Volume 24, Issue 1

- Ikelegbe, A. (2005) The Economy of Conflict in the Oil Rich Niger Delta Region of Nigeria Nordic Journal of African Studies 14(2): 208-234

- Ikelegbe, A. (2006) Beyond The Threshold Of Civil Struggle: Youth Militancy And The Militia-Ization Of The Resource Conflicts In The Niger Delta Region Of Nigeria. African Study Monographs, Vol., 27, Issue 3

- Rogers, P. \& Hall, A. (2003). Effective Water Governance. Global Water Partnership, TEC Background Papers, No. 7.

- Suleiman, M. N. \& Karim, M. A. (2015) Cycle of Bad Governance and Corruption: The Rise of Boko Haram in Nigeria. Sage Open, January-March: 1-11

- Terwase, I. T., Abdul-Talib, A. N. \& Zengeni, K. T. (2015). Conflict Resolution: the Truncated Zoning Arrangement and the Buhari Political Tsunami in Nigeria. Journal of Government and Politics, Vol.6 No. 2

- Terwase, I. T., Abdul-Talib, A. N., Zengeni, K. T. \& Terwase, J. M. (2015). The Psychological Trauma on Boko Haram Victims in Nigeria: Conflict Resolution Perspective. Mediterranean Journal of Social Sciences, Vol 6, No 6 S4

- Uzokwe, A. O. (2003) Surviving in Biafra: the story of the Nigerian civil war: over two million died. Writers Advantage, an Imprint of iUniverse, Inc. Lincoln, USA.

- Walker, A. (2012). What Is Boko Haram? United States Institute of Peace, Special Report, 308 June

- Onapajo, H., \& Uzodike, U. O. (2012). Boko Haram terrorism in Nigeria: Man, the state, and the International System. African Security Review, 21(3), 24-39.

- Onapajo, H., Uzodike, U. O., \& Whetho, A. (2012). Boko Haram terrorism in Nigeria: The international dimension. South African Journal of International Affairs, 19, 337-357. 